\title{
From Habsburg to Hitler to Haider: The Peculiarities of Austrian History
}

Harry Ritter

Western Washington University, harry.ritter@wwu.edu

Follow this and additional works at: https://cedar.wwu.edu/history_facpubs

Part of the European History Commons

\section{Recommended Citation}

Ritter, Harry, "From Habsburg to Hitler to Haider: The Peculiarities of Austrian History" (1999). History Faculty and Staff Publications. 38.

https://cedar.wwu.edu/history_facpubs/38 


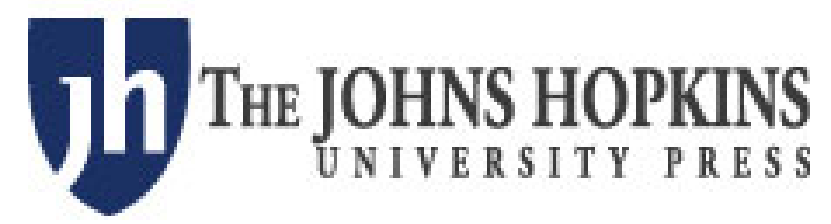

\section{German Studies Association}

From Habsburg to Hitler to Haider: The Peculiarities of Austrian History Author(s): Harry Ritter Source: German Studies Review, Vol. 22, No. 2 (May, 1999), pp. 269-284

Published by: The Johns Hopkins University Press on behalf of the German Studies Association Stable URL: http://www.jstor.org/stable/1432076

Accessed: $29 / 10 / 2014$ 16:10

Your use of the JSTOR archive indicates your acceptance of the Terms \& Conditions of Use, available at http://www.jstor.org/page/info/about/policies/terms.jsp

JSTOR is a not-for-profit service that helps scholars, researchers, and students discover, use, and build upon a wide range of content in a trusted digital archive. We use information technology and tools to increase productivity and facilitate new forms of scholarship. For more information about JSTOR, please contact support@jstor.org. 


\title{
From Habsburg to Hitler to Haider: The Peculiarities of Austrian History
}

\author{
Harry Ritter \\ Western Washington University
}

In broad overview, the defining feature of Austrian history since 1866 has been dramatic and - since 1918 - sometimes wrenching change.* A greater contrast between the country's serene, touristic image and the real historical experiences of its people can scarcely be imagined. Other regions - Poland, the former Yugoslavia, the former Soviet Union - endured, to be sure, greater human extremes and far greater total misery in our century. Sadly, the plight of these nations often occurred at the hands of Austrian-bred officials and soldiers, from Hitler, Eichmann, Globocnik, and Kaltenbrunner on down. ' Yet if other countries suffered more, few, in such a brief time-span, were reimagined and reinvented so often, in so many ways — politically, geographically, emotionally. Small wonder that "identity" has long been a quandary of Austrian life. Even casual observers of Austria's modern past could roughly trace its radical peaks and valleys:

...Habsburg Austria's exclusion from Bismarck's emerging north German Reich following defeat in the Austro-Prussian War of 1866;

...the final collapse of the centuries-old Habsburg dynastic state at the end of World War I;

...creation of a derelict German-Austrian republic from (in Clemenceau's phrase) "what was left over" once the empire's non-German successor states were formed;

...the short but savage 1934 civil war and creation of the Dollfuss dictatorship at the height of the Great Depression - an entity which lacked, however, solid popular support

...the absorption of dwarf Austria - der Staat, den keiner wollte $^{2}$ - into Hitler's Third Reich in 1938, with the uneven compliance of a majority (though far from all) of its citizens;

...rapid industrialization of parts of the alpine region in the context of Nazi Germany's war economy, abruptly accelerating modernization; 


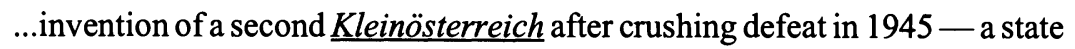
ambivalently regarded by the victors as, on the one hand, the "first victim of Hitlerite aggression" and, on the other, a conquered foe requiring a decade of alien occupation and reeducation;

...and creation of a small, neutral republic under the State Treaty of 1955 sovereign, yet still lacking (in the minds of many of its residents) a secure sense of its legitimacy as a nation.

Recurrent, destabilizing change, then, has been the signal attribute of Austrian Zeitgeschichte, and new shifts are occurring today, a subject to which this article will return at its conclusion. But the main purpose of this essay is to highlight some peculiar Austrian continuities of the long and medium term, or at least patterns of change slow to unfold, chiefly on the level of values, mental habits, political culture, and interactions between society and institutional structures.

The first of these continuities is underscored in the title of Ernst Hanisch's impressive new history of Austria between 1890 and 1990, Der Lange Schatten des Staates: Österreichische Gesellschaftsgeschichte im 20. Jahrhundert. ${ }^{3}$ Greeted with controversy in Vienna, Hanisch's panorama represents nonetheless a benchmark for future efforts to understand modern Austria's stormy experience; anyone seeking a reliable guide to the landmarks of contemporary Austrian history and a balanced appraisal of its key issues will be well advised to start with this study.

In the first third of his book, Hanisch identifies deep structures of Austria's early modern and modern longue durée - cultural traditions, mentalités, elite and popular behavioral patterns, demographic and economic trends - stretching back to the conflicting legacies of the Baroque Age and the Josefinian Enlightenment. Despite formidable tensions between these two grand traditions (Baroque spirituality, love of ceremony, hierarchy, plenitude, and the ornate; Josefinian austerity, simplicity, practicality, reductionism, and rationality), they nonetheless interlaced to cast the "long shadow" of legalistic culture, bureaucratism, and the cameralist state over subsequent Austrian history, right down to the present day. ${ }^{4}$ Equivocal in its implications, the shadow of early-modern étatism rendered Austrians illprepared for pluralist democracy and autonomous individualism yet ironically, in the long run, eased the path to today's "social partnership," social-liberal welfare society, and regulatory state. Overall, Hanisch - a self-professed product of Austria's Catholic political heritage - gives his story (almost despite himself) a liberalizing twist; he emplots it as an arduous, dialectical expansion of individual "life chances" (Ralf Dahrendorf's term) over against the deep-seated authoritarian and antiliberal structures of Austrian life - Catholic tradition, anti-Semitism, and authoritarian mindsets. At the same time, his voice is modulated by an ironic tone relating to these liberalizing and emancipatory processes - one alert to the unheroic side of human behavior so abundantly demonstrated by the recent Austrian past, and mindful of the losses, complexities, and future uncertainties as well as the gains produced by modernization. 
Within Hanisch's statist framework, one must stress the persistence and slow transformation of legalistic values revolving around group status and the protection (via alliance with the state) of group entitlements and interests - in short, the values of corporatism. Thirty years ago, invoking corporatism as a conceptual guide to serious scholarship would have raised arched eyebrows, and even today it excites mixed emotions. A modern version of the ancient notion of corporatism was notoriously fashionable as a social nostrum in right-wing circles of the early twentieth century; after 1922 it acquired a powerful stigma in the minds of western progressives - liberals and socialists alike — due to its association with Mussolini's Fascism and its emulators. One of these imitators was precisely the 1930s Austrian dictatorship of Engelbert Dollfuss and Kurt von Schuschnigg - a political cul-desac that remains an embarrassment in Austria today, almost as much as the Nazi regime itself. In the 1970 s, however, the corporatist taboo was refurbished by political scientists interested in interactions between interest groups and the neoliberal regulatory state, and there is now a swelling literature on its relevance to social science. ${ }^{5}$ (To avoid confusion over terms, it should be noted that this essay uses the expression "neoliberal" in the sense of "social liberalism" - as born in the era of Friedrich Naumann - as opposed to the doctrine of the unrestrained free market, as the word is sometimes employed nowadays).

Philippe Schmitter, a leader in the renaissance of interest in corporatism, describes contemporary social corporatism as:

a distinctive way of organizing interests and influencing public policy.... one of several possible arrangements through which interest associations can intermediate between their members (individuals, families, firms, groups of all kinds) and their interlocutors (especially agencies of the state with authority and other resources to satisfy their demands). ${ }^{6}$

In the schematic parlance of political science, Schmitter contrasts corporatism (characterized by such features as "monopolistic units," "hierarchichal coordination," and "devolved implementation") with "pluralism" (distinguished by "multiple units," "autonomous interaction," and "persuasive conviction").

Many authorities would concur that, in Austria, membership in the type of legally defined corporate bodies described by Schmitter remains a benchmark of identity and social possibility - i.e., an Austrian Sonderbewusstsein. ${ }^{8}$ This has mitigated the definitive triumph of a pronounced individualist and free-market ethos such as that associated with a group of late-nineteenth-century Austrian economists now known (somewhat paradoxically, considering the small resonance their doctrines had in post-1918 Austria itself) as the "Austrian School" of economic theory. Among scholarship's unfinished tasks is the rigorous grounding of the work of these thinkers - Carl Menger, Friedrich von Wieser, and Eugen von BohmBawerk - in the context of late- nineteenth-century Austrian life. ${ }^{9}$ They were 
drawn to Smithian liberalism precisely because the antithetical assumptions of the Baroque and Josefinian Polizeistaat persisted so strongly and often oppressively in the Austria of their day. Yet even within the Menger school there were echoes of the regulatory Obrigkeitsstaat. Despite their heretical attraction to laissez-faire, their thought patterns had substantial cameralist roots. ${ }^{10}$ They too labored under the "long shadow of the state," and Böhm-Bawerk became one of the state's leading minions as Habsburg finance minister on different occasions between 1895 and 1904. It was only a later generation of "Austrian" theorists, led by Ludwig von Mises and Friedrich von Hayek, who developed a full-blown antistatist version of Menger's ideas - and they had to do it mainly in Anglo-American exile. ${ }^{11}$ In many ways the economics of Josef Schumpeter - with its stress on institutions and governments as well as markets and heroic entrepreneurs - was a more logical extension of the founders' ideas, especially those of Wieser. It would, perhaps, be instructive to consider the ideas of the late Wieser, or even the late Menger (if not Böhm-Bawerk) in relationship to nascent currents of Austrian social liberalism represented by someone like the liberal parliamentarian and (briefly) Minister of Trade Josef Maria Baerenreither. ${ }^{12}$

Unlike the Austrian Economic School, scholarship is amply acquainted with the array of romantic and reactionary corporatism that flourished in Old Austria those of Adam Müller, Karl Baron von Vogelsang, and other precursors of Hugo von Hofmannsthal's neo-Baroque, oxymoronic crusade for konservative Revolution after 1918, of the holist sociology of Othmar Spann, and ultimately the Fatherland Front of Dollfuss and Schuschnigg. In practical terms, however, just as significant as such neoconservative ideas for transforming yet perpetuating the corporatist heritage were the chambers of commerce and industry and the weighted voting classes (curia, or electoral colleges) that evolved after 1848 as nonegalitarian mechanisms for representing special interests in the emerging age of mass politics. These institutions were championed not by antimodernists, but precisely by the liberals that men like Müller and Vogelsang despised, showing that antimodernists held no monopoly on the corporate paradigm, and that - in the Austrian context - progressivism and corporatism were perfectly compatible. (And after 1945 it would become clear how compatible corporatist paradigms were with social democracy - which, pragmatically speaking, began evolving into a form of neoliberalism after the 1880s.) In fact (and this is perhaps the main thesis of the present essay), one way to broadly imagine modern Austrian history since 1848 might be in terms of a counterpoint between liberal and nonliberal variations on the corporatist theme-counterpoint being understood here in something close to its literal musical sense, i.e., "melody not single, but moving attended by one or more related but independent melodies." ${ }^{13}$ (Again, to avoid confusion, the expression liberal corporatism is used here to mean corporatist arrangements within the framework of the existing or emerging parliamentary/democratic Rechtsstaat.) 
In view of its overall lack of success as an organized political movement in Austria (reaching its nadir in the 1930s and early 1940s), the suggestion that liberalism might help us understand the peculiarities of Austrian history might seem far stranger than the appeal to corporatism. Indeed, a key motif of Hanisch's imposing survey - even though its narrative commences in the heyday of cultural liberalism, the $1890 \mathrm{~s}$ - is the persistence in Austria of a popular Untertanenmentalität and the weakness of liberalism, parliamentary institutions, and civil society generally. Granted, in Austria (as in Bismarck's Germany) liberalism operated under significant restraints right from the outset of the parliamentary era in 1867, since its delegates had no solid control over the appointment and tenure of cabinets or over military budgets. Moreover, upper middle-class Honoratiorenliberalismus suffered sobering setbacks after 1879 at the hands of Count Taaffe's "iron ring" coalition of Slavs, federalists, and clericals (on the imperial level) and (in Vienna) amidst the rise of mass political movements of the irrational "sharper key" (schärfere Tonart): Socialism, Christian Socialism, illiberal nationalism, and anti-Semitism. ${ }^{14}$ These counterliberal factors assumed preeminence after 1945 in the minds of scholars understandably intent on uncovering the roots of political extremism and totalitarianism in Austria - e.g., Adam Wandruszka's classic, 1954 analysis of “Österreich's politische Struktur," Carl Schorske's studies of fin-de-siècle Vienna, and John Boyer's books on Karl Lueger. ${ }^{15}$

Yet despite such stress on the demise of Honoratiorenliberalismus, nineteenthcentury liberals did create the rudiments of a civil society and legal culture that would - though often deeply submerged - endure as a liberal strain in Austrian history. ${ }^{16}$ What is important, in this regard, is not so much liberalism viewed as a parliamentary faction, but liberalism understood more broadly as an evolving spectrum of values, traditions, organizational models, and legal institutions leading toward enhanced freedoms, life chances, opportunities, and human rights. The subject of north German liberalism has lately drawn increased attention within the context of comparative history, Habermas's idea of the public sphere, and the work of David Blackbourn and Geoff Eley. ${ }^{17}$ Gerald Stourzh, in the 1986 introduction to a group of essays on Habsburg-era roots of Austria's present "social partnership," devoted serious attention to nineteenth-century liberal currents in the history of Austrian labor relations; and since 1996, Austro-German liberalism has its social historian, with the appearance of Pieter Judson's prize-winning survey of the years 1848 to 1914, entitled Exclusive Revolutionaries. ${ }^{18}$ Neither the north nor southGerman liberal traditions may exactly fit the image of British liberalism so often used as the benchmark for all liberalisms (even by Central European liberals themselves), but Blackbourn and Eley have amply demonstrated the fallacy of judging all liberalisms by an idealized English standard - even British liberalism itself. $^{19}$

As just noted, liberalism suffered crippling political and philosophical setbacks in the $1880 \mathrm{~s}$, but they were not terminal. The middle-class German left 
was not moribund, but evolving. In the context of Habsburg Austria's liberalcorporatist/neo-Josefinian Rechtsstaat - satirized (not without reason) as a legalistic nightmare by Kafka and Musil - liberals of the fin-de-siècle modified the universalist ethos and staid and aloof strategies of their mid-century predecessors, moving freisinnig politics toward a less generous national liberalism and Interessenpolitik. As Lothar Höbelt shows in his book Kornblume und Kaiseradler, ${ }^{20}$ they discovered (as the American congressman Tip O'Neill later said) that "all politics is local," and that political success in a democratic age and under Old Austria's polyglot conditions demanded the articulation of local interests, concerns, and fears. ${ }^{21}$ This political tropism is often read narrowly and against the historical grain, as a slippery slope toward the racialist Germanomania of Georg von Schönerer, understood as portent of Hitler. Hitler certainly cited Schönerer as a model, but neither Schönerer nor Hitler himself would now be remembered if not for World War I and the strange contingencies created by its aftermath. ${ }^{22}$

One-dimensional focus on prewar extremists diverts the spotlight from the successes of mainstream national liberals in the hybridized liberal-corporatist culture of Austria prior to 1914, and inhibits appreciation of the potential vitality of that political culture itself, as well as its relevance for today's Austria. Granted, mainstream national liberalism moved in a more ethnocentric, populist direction, and its rhetoric was frequently strident, often embracing (depending on the locality) anti-Czech, anti-Slovene, or anti-Semitic conceits. The fact that it became less generous does not disqualify it as liberalism, however, for ungenerous liberalisms abounded at the time - not least in Britain and America.

It would be foolish to deny that national liberalism's adjustments were devoid of disquieting potential, ${ }^{23}$ or to speculate on the survival chances of Old Austria's political culture in the absence of World War I. What is clear is that, with its tactical modifications, pre-1914 liberalism remained quite successful in regional and municipal politics outside Vienna, domain of the renegade liberal Lueger. ${ }^{24}$ Schorske's interpretation (based in turn on Wandruszka) depicted Austrian politics as tending only toward so-called "post-liberal" radicalism, but pre-1914 Austria included more than Vienna and was laden with other possible outcomes. ${ }^{25}$

Thus, a hybridized liberal/bureaucratic framework for civil society - and the rudiments of a political culture to flesh it out - were indeed serviceable legacies of Old Austria to its successor states. True, as Wolfgang Mantl suggests, ${ }^{26}$ under the world economic and geopolitical circumstances that followed World War I those rudiments could not take root, and acute political dysfunction was the consequence. There was a dramatic eclipse of Austrian liberalism and, some feared, all other liberalisms worldwide. In that setting, there never could be a mass-based liberal Lager; the very word "liberal" was additionally burdened in the Austrian context by associations with the 1873 stock market crash and philo-Semitism. What happened in Weimar Germany more gradually - the contraction of the liberal middle and its absorption into polarized factions - was already largely a fact in 
Austria in 1919, confirmed by the resounding failure of the still-born BürgerlichDemokratische Partei in the elections of that year. Even today the term liberal remains a political liability, a situation complicated by the persistent Marxist myth that liberalism was really a way station for fascism, and the fact that after 1945 the words liberal, freiheitlich, and what was left of the old national liberal tradition were often used as havens by ex-Nazis. ${ }^{27}$ There is surely much to the notion that, in the bewildering conditions after 1918, the diverse corporatist mindsets of the prewar period helped create a disposition to support, underestimate, or otherwise fail to comprehend the related but distinctly new phenomenon of fascist corporatism based on radically new concepts of the state, the law, and the individual. ${ }^{28}$ On the whole, however, I would argue that in interwar Austria (as in Germany) the triumph of illiberalism was less the result of decline that set in before 1914 than the product of short-term contingencies created by the radicalizing engine of the Great War. The war was indeed a massive cleavage; it was this "radical rupture," as one recent author correctly affirms, that "more than any kind of perceived continuity between pre- and postwar German society...produced National Socialism in Germany - and fascism in other countries." 29

Still, revisionist socialism was not swamped by the war, and by the 1920 s German and Austrian Social Democracy (beneath their often extremist rhetoric) had become potential conduits for revisionist liberalism and liberal corporatism, should favorable conditions arise. After 1945, amidst new circumstances produced by Hitler's defeat and the advent of the Cold War, a hybridized neoliberal corporatism strongly indebted to the statist, bureaucratic, and legalistic political culture of the late Habsburg past supplanted the antiliberal corporatisms that dominated between the wars. To be sure, native liberalism's final victory came only after native illiberalisms were crushed by foreign powers, and following a decade of alien occupation. But, after all, ten years is not so long a time, and without substantial roots in the modern past the new neoliberal system could not have taken hold.

In this setting, the hermetically sealed Catholic, socialist, and nationalist Lager that arose in the $1880 \mathrm{~s}$ - that polarized Austria after 1918 and reduced it to civil war in the 1930s - were recast into neocorporate frameworks for parity, patronage, mutual consultation, conflict resolution, and resource allocation. What formerly divided the country now held it together. The parties to this Sozialpartnerschaft did not call themselves liberals, but Socialists and Christian populists, and their leaders were certainly not inspired by feelings of kinship with older liberal traditions. Their actions were often motivated by the narrowest cynicism and expediency. ${ }^{30}$ The words freiheitlich and liberal, still redolent of musty positivism, dogmatic anticlericalism, and Austro-German progressivism's more ethnocentric and exclusionary "national liberal" turn on the eve of World War I, were left to the dregs of the nationalist Lager - fatally discredited by its association with Hitler (though its members were eagerly recruited by the Socialist and Christian democratic parties). 
Or, the term liberal was understood pejoratively in a doctrinaire laissez-faire sense, as alien to Austrian life, a one-dimensional interpretation that seemed ironically reinforced by the antistatist views of the Austrian exile Hayek - to the extent that these ideas were known at all in post-1945 Austria.

Efforts to weld a non-Socialist and non-Catholic third party option from diverse middle class, nonunionized, displaced Volksdeutsche, and ex-Nazi constituencies, culminating in creation of the Freiheitliche Partei Österreichs (FPÖ) in 1955, remained factionalized, programmatically unstable, and easily stigmatized as rightist and extremist - not least because the first two FPÖ leaders were, respectively, a former minister in Seyss-Inquart's Anschluss cabinet of 1938 (Anton Reinthaller), and an ex-member of the Waffen-SS (Friedrich Peter). Initially ostracized, the party enjoyed minimal electoral success prior to the late 1980s (although the Realpolitiker Bruno Kreisky shrewdly employed the small party to sustain Socialist cabinets between 1970 and 1983, and the FPÖ was even embraced as a Socialist coalition partner from 1983 to 1986). Beneath the language and surface static of histoire événementielle, however, postwar Austria became a capitalist welfare state of the neoliberal type, erected on neocorporate arrangements and linked economically to West Germany (which allowed it to prosper). And West Germany, in its own peculiar way, exhibited pronounced neocorporatist features that stretched back through the Weimar to the Wilhelmine period. As usual, the peculiarities of Austrian history evolved in the context of a broader Germanlanguage framework of historical peculiarities. ${ }^{31}$

While citizens of the reinvented state were still not sure if they were "Austrians," "Germans," "Viennese," "Tyrolese," or kinfolk of some other Heimat, most of them relished the social peace, affluence, and material security sustained by the system. Still, the new Kleinösterreich was not in every respect ideal. ${ }^{32}$ In broad terms, Philippe Schmitter has described the downside of neocorporatist practices for any society:

Although the finding that corporatist arrangements contribute to "governability" through greater citizen compliance, and fiscal effectiveness seems widely accepted, the suspicion persists that they surreptitiously undermine democracy. Organizations replace persons as the principal participants; specialized professionals gain at the expense of citizen amateurs; direct functional channels of representation to state agencies displace territorially based legislative decision making; monopolies and privileged access are recognized at the expense of overlapping and competing associations; comprehensive national hierarchies diminish the autonomy of local and specialized organizations. ${ }^{33}$

Added to these negatives are complications produced by global change: the collapse of Soviet Communism and end of the Cold War, population pressures created by attendant migrations from the south and east, advancing European 
integration (including Austrian membership in the EU in 1995), and fiscal strains within the neoliberal welfare state, world wide. Since 1989, amidst the altered setting produced by such changes, it has become fashionable to speak of a "new political landscape" and impending "paradigm shift" of political cultures in the second Austrian republic.

In today's geopolitical setting it is not (to recall Friedrich Hebbel's famous nineteenth-century remark) a matter of imperial, great power Austria serving as a microcosmic theatre where the wider world conducts its rehearsals. ${ }^{34}$ It is rather a question of a small European country where - after a few decades of cozy consensualism in which most people generally knew their place and how to play the game - global insecurities intrude and enter their phase of residuals and reruns. ${ }^{35}$ The issue for today's Austria is one of adjustment to rapidly changing circumstances by a country which, under the postwar collusion of Socialist and Christian Social elites, created (as outlined above) a de facto system of social-liberal corporatism in the 1950s and 1960s. Building on tourism and an industrialized base of nationalized enterprises inherited from the Third Reich and which remained linked to West Germany's dynamic economy, Austria entered the ranks of advanced industrial economies, but remained (obviously) smaller and relatively less modern than the leading world economies (e.g., its greater reliance on heavy industry, greater labor intensiveness, etc.) The collapse of the Soviet empire in 1989 and Austria's entry into the European Union were merely culminating events in an evolution of circumstances which brought to a head an "erosion of traditional [ideological] subcultures, social fragmentation and particularization, and processes of individualization." 36 For politics in the 1990 s this means fractionalization, identity politics, the rise of new interest groups and parties, and a new, late twentieth-century "sharper key" in rhetoric. It is these historically specific conditions of the 1980 s and 1990s that impact present Austrian social structures and voter behavior, and that are mainly behind the illiberal protest populism exemplified by Jörg Haider and the revamped FPÖ today - not a vestigial fascism or "unmastered past." Diethelm Prowe is correct in maintaining that the new wave of populism in Europe is not a reprise of interwar fascism. ${ }^{37}$ "Classic" fascism (as Ernst Nolte argued) should be understood in its interwar setting, and we need new terms and categories to designate movements that arise from late twentieth and early twenty-first century conditions. This is not to deny the many disturbing aspects of the new populism. And it is not to trivialize the issue of an unmastered past. The past is indeed in the present, and its unmastered aspects are clearly important for the ways Austria's scholars, novelists, and mass media conceptualize the country's history, which in turn affect people's present behavior and their visions of the future. It is just that the issue of an unconquered past should not be confused with the mainsprings of present political dynamics. Like the older extremism, the new populism is a product of social alienation, but that malaise is not akin to the victimization psychosis and antimodernist nostalgia that fed fascism in the 1920s and 1930s. The roots of protest 
populism today do not lie in the estrangement of Austrian voters from the conditions of modern life - democratization, industrialization, secularization, urbanization - but in fear (increasingly among blue collar workers) that the fruits of these very modern conditions - secure jobs, affluence, and welfare safety nets - will be lost.

In a sense, the inventors of post-1945 Austria's black-red consensualism were too successful. They fashioned a model welfare state which integrated ordinary Austrians into modernity. But problems arise when this ingrown elite cannot quarantine its creation from external change, and also succumbs to the corrupting seductions of wealth and power based on old-boy networks and bureaucratic bloat and inbreeding. Nimble opportunists such as Jörg Haider will, not surprisingly, arise to capitalize on resentments over the "politics as usual" corporatism of mismanagement, waste, and personal enrichment, and will exploit fears that the modernizing achievements of this very corporatist system will be squandered. In his frequent reliance on the tactics of negative integration, the "telegenic" Haider may indeed recall der schöne Karl Lueger of a previous fin-de-siècle; his speech, and the unspoken lines between it (like that of Lueger before him), is reckless and stretches the boundaries of "civil" discourse-a notoriously sensitive issue in German-speaking Europe, precisely because of that region's troubled recent past. But the global, European, and local setting in which Haider operates is rather different from the world of Lueger.

From a new turn-of-the-century standpoint, one may hazard some final thoughts regarding Austria's position in Europe, the current language of scholarship and politics, and the historiographical and political relevance of Austria's liberal tradition. The thought of instrumentalizing heritage, or "memory," as a means to noble or ignoble ends, of constructing "usable" pasts to promote current agendas, must properly haunt those who honor the past's alien integrity - for the good of present and future as well as the past itself. Nowhere have orchestrations of history been more notoriously abused than in modern Central Europe.

Yet past and present are existentially inseparable. Liberalism, as this essay has argued, has demonstrated vastly more staying power than pundits predicted in the troubled aftermath of World War I and the Great Depression, or even in the more hopeful wake of World War II. Nowhere, in those days, did liberalism's future look more bleak than in Germany and Austria. Today, self-styled "Liberal" parties remain relatively weak sisters in the middle European political game (the FDP, the FPÖ). Yet who could deny that, at the end of our short twentieth century, neoliberal structures govern the limits of the possible in Central and Western Europe, and free market rhetoric controls global political discourse? As Austrians, in this world setting and in the course of a new kind of Anschluss, engage the German- and French-led process of European Union, sharing the challenges of inventing that emerging polity, they may gradually find it increasingly natural to attend more closely to thecomparative study of liberalism in its many guises, to attach greater value to Central European liberalism's peculiar native roots, and to allow a critical regard for Austria's own liberal traditions larger room in their psychological space. 
In a modest way, something of the sort has been going on for some time now to the north, in the scholarship and political discourse of the German Federal Republic. Despite the still unmastered pall of Berlin's illiberal past, the task of unearthing the history of Central European liberalism is, in fact, slightly easier in Germany, where the liberal Freie Demokratische Partei - despite its small electoral base - played a key national role as a coalition party from 1949 to the late 1990s. In displaced form a new interest in the liberal heritage is actually manifest in Austria, in the guise of heightened interest in middle-class social history, civil society, and bürgerliche culture during the late Habsburg period. Excavation of liberalism's legacy in Austria can only happen slowly, for in the historical context of the region's political semantics the word and idea of liberalism must be disentangled from its peculiar liaison with the tactical rhetoric of late nineteenthcentury national progressivism and emerging deutschnational populism, ${ }^{38}$ an idiom ironically reinforced by political speech under post-1945 contingencies.

In this connection, perhaps the most interesting Haider in Austria today is not so much Jörg but the historian Barbara Haider. She is the author of the Austrian Academy of Sciences' new edition of the protocols of Habsburg Reichsrat's committee of constitutional inquiry during late $1867,{ }^{39}$ when nineteenth-century Austro-German liberalism completed one of its chief tasks: the transformation of the monarchy's western half into a parliamentary Rechtsstaat. The catalog of civil rights produced by this committee later became the backbone of Austria's first republican constitution in 1920, and underpins the Second Republic's constitution of today. In light of the relatively slight explicit attention that even recent Austrian historians have given to liberalism as a strain in Austria's modern past, it is noteworthy that Barbara Haider deliberately presents her work as a "small piece of the puzzle known as the "history of liberalism," in Central Europe ${ }^{40}$ Her introduction to the protocols is a judicious appreciation of the fact that midnineteenth century Austrian liberalism, despite its manifold shortcomings from present perspectives, created the foundations of a civil society and political culture that would - though often deeply submerged - endure and become part of a liberal strain of deep structural continuity in modern Austrian history.

Two or three decades ago, a book such as this might have been presented as something more abstract and less immediately relevant to present concerns - a contribution to Old Austria's Staats- und Reichsproblem, the history of the empire's presumed terminal dysfunctionality, the nationality problem, or the political dregs of the 1867 Ausgleich. Haider's gloss of the documents is a model of historiographical tact, one that situates the protocols firmly in the psychic space and social circumstances of their own time. Yet despite her healthy respect for old-fashioned Verstehen, the fact that she conceptualizes her book not only as a contribution to Austria's "constitutional and parliamentary history," but to the history of liberalism as well, seems-under present circumstances-not merely historiographically significant but politically aktuell. 
Looking backward - and without minimizing the powerful illiberal strands of Austrian history (one would be utterly blind to do so) - the story of Austria between 1848 and 1998 looks less like one of liberalism's defeat than one of liberal continuity, with a spectacular illiberal hiatus between the Dollfuss dictatorship of the 1930's and annihilation of the Anschluss dystopia in 1945. Or, perhaps, it has been a roller coaster with more or less significant liberal upturns: $1848-1849$, the years from 1867 to 1914 , the first republican ordeal of the $1920 \mathrm{~s}$, the era since 1945. If the "puzzle" of liberalism ever does become a major focus for research in Austrian history, perhaps Austrians will be slightly better equipped, in terms of enhanced awareness of part of their heritage, to confront twenty-first- century membership in a European Union in which liberalism - in one guise or another (as a Times Literary Supplement headline recently declared) — is "the only ideology still afloat." 41

\section{Notes}

*This is a revised version of a luncheon address delivered to the German Studies Association in Salt Lake City, October 9, 1998. I am indebted to Professor Edward Kaplan of Western Washington University for his comments on the paper. An earlier version was presented at the Third Symposium on German History at the University of British Columbia, May 24, 1997. Some of the essay's language and ideas previously appeared in book reviews for the journal Central European History and for the on-line discussion group HABSBURG.

'On the other hand, the extent of Austria's suffering - for whatever reason - must not be minimized. According to official figures relating to the Nazi era, 65,459 Jewish Austrians were killed; among non-Jewish Austrians, 2,700 were executed, 32,600 perished in Gestapo prisons or concentration camps, 24,300 civilians died during the war, and 247,000 soldiers were killed in battle or missing in action. This amounts to 5.58 percent of the population. Dieter A. Binder, "The Second Republic: Austria Seen as a Continuum," Austrian History Yearbook, 26 (1995): 18, n. 3.

${ }^{2}$ Helmut Andics, Der Staat, den keiner wollte: Österreich 1918-1938 (Vienna, 1962).

${ }^{3}$ Vienna, 1994.

${ }^{4}$ From the standpoint of state-building - aside from their piety, parent/child disfunctions, and capacity for patience - there was less opposition and more continuity between Maria Theresa, epitome of the Baroque, and her enlightened son Josef than used to be thought. For a recent study, see Derek Beales, Joseph II (Cambridge, 1987), volume I.

'Philippe C. Schmitter, "Corporatism," The Oxford Companion to Politics of the World, ed. Joel Krieger (New York, 1993), 195-98.

${ }^{6}$ Ibid., 195-96.

${ }^{7}$ Ibid., 198. Schmitter describes pluralism as the more characteristic mode of organizing interests and influence in the "advanced industrial polities" (196) of the mid- and late twentieth century. Indeed, he believes that cases of societies marked by a high degree of institutionalized corporatism have been "relatively rare" in history (196). At the same time, however, he discerns a late- twentieth -century trend in the direction of corporatism; for better 
or worse, he suggests, all advanced democracies are currently veering from the "spontaneous, voluntaristic, and autonomous features of pluralism" toward more structured, organized interest representation and vicarious (rather than direct) participation on the part of individuals - traits typical of neocorporatism. Today, Schmitter believes, "democracy is being transformed by modern corporatism.... Organizations are becoming citizens alongside individuals. Accountability and responsiveness are increasing, but at the expense of citizen participation and access for all groups. Competition is less interorganizational and more intraorganizational.... all modern democracies are becoming more 'interested,' organized, and vicarious" (198).

${ }^{8}$ Austria, Norway, Sweden, Finland, and the Netherlands are frequently cited as the best-case examples of neocorporatism in the contemporary world. Referring to a chart designed to juxtapose the ideal-typical features of the "pure corporatist" versus "pure pluralist" model of representation and control in current societies, Schmitter asserts: "No existing polity exactly replicates the arrangement summarized in either column, although Austria comes closest to the former and the United States to the latter" (Schmitter, "Corporatism," 196) (emphasis added). For a good exploration of the subject, and many references to the relevant literature in political science, sociology, and history, see the essays in Günter Bischof and Anton Pelinka, eds., Austro-Corporatism: Past, Present, Future, Contemporary Austrian Studies, 4 (New Brunswick, N.J., 1996).

${ }^{9}$ Some helpful steps in this direction have been made in numerous essays on the history of Austrian economic theory by the University of Vienna economist Erich Streissler and in an unpublished 1984 University of Chicago doctoral dissertation by Paul Silverman on "Law and Economics in Interwar Vienna: Kelsen, Mises, and the Regeneration of Austrian Liberalism."

${ }^{10}$ Paul Silverman, "The Cameralistic Roots of Menger's Achievement," History of Political Economy,22 (1990), supplement: 69-91. For a good appreciation of the importance of Austrian legalism and administrative culture for the Austrian economic theorists, consult Silverman's dissertation, "Law and Economics in Interwar Vienna" (see note 9).

"Mises, a student in Böhm-Bawerk's seminar, was perhaps influenced by the latter's Laocoön despair over his inability to promote reform as finance minister amidst the coils of bureaucratic hypertrophy. I owe this idea to a suggestion by Erich Streissler.

${ }^{12}$ On Baerenreither, see Everhard Holtmann, “'Sozialpartnerschaft' und 'Sociale Frage': Korporatistische Tradition in Österreich: Der Ständige Beirat des Arbeitsstatistischen Amtes als Beispiel paritätischer Interessenvertretung in der Späthabsburgerzeit," Der Staat 27 (1988): 244-49. On Schumpeter, see the recent flurry of studies: Eduard März, Joseph Schumpeter: Scholar, Teacher and Politician (New Haven, 1991); Richard Swedberg, Joseph A. Schumpeter: His Life and Work (Cambridge, 1991); Robert Loring Allen, Opening Doors: The Life and Work of Joseph Schumpeter, 2 vols. (New Brunswick, N.J., 1991). Erich Streissler designates Wieser (albeit somewhat ironically) as the "central figure of the Austrian School" in his essay "Arma virumque cano: Friedrich von Wieser, the Bard as Economist," in Norbert Leser, ed., Die Wiener Schule der Nationalökonomie (Vienna, 1986), 104. As Lothar Höbelt notes, "thoroughgoing Manchester Liberals were scattered fairly thinly among Austrian Liberals. The dominant centrist group of the Liberals almostunequivocally supported the protective tariff; it was only the Progressives - and not even all of them - that voted against the Tariff Bill of 1878. But even they did not regard it as a major issue. 
${ }^{13}$ Webster's Collegiate Dictionary, 5th edition (emphasis added). On the general question of the appropriateness or inappropriateness of using the words "liberal" and "corporatist" in tandem, note the remarks of Schmitter, "Corporatism," 196: "In the mid-1970s, a group of scholars revived the concept [of corporatism] to describe and explain certain puzzling features of advanced industrial democracies that could not be understood by the heretofore dominant paradigm, pluralism. To differentiate the new variety from discredited previous experiences, these scholars usually added a prefix such as 'liberal,' 'societal,' or 'neo-' to the corporatist root."

$\rightarrow{ }^{4}$ Carl E. Schorske, "Politics in a New Key: An Austrian Triptych," Journal of Modern History 39 (Dec. 1967): 343-86.

${ }^{15}$ Adam Wandruszka, "Österreichs politische Struktur," in Heinrich Benedikt, ed., Geschichte der Republik Österreich (Vienna, 1954); Carl Schorske, Fin-de-Siècle Vienna: Politics and Culture (New York, 1980); John W. Boyer, Political Radicalism in Late Imperial Vienna: Origins of the Christian Social Movement, 1848-1897 (Chicago, 1981); idem, Culture and Political Crisis in Vienna (Chicago, 1995).

$\rightarrow$ SSee also Harry Ritter, "Austro-German Liberalism and the Modern Liberal Tradition," German Studies Review 7 (May 1984): 227-48. For a judicious critique of older survey histories and balanced appreciation of more recent work on Habsburg Austria's emerging civil society and politics of democratic engagement, consult Gary B. Cohen, "Neither Absolutism nor Anarchy: New Narratives on Society and Government in Late Imperial Austria," Austrian History Yearbook 29, Part I (1998): 37-61.

${ }^{17}$ David Blackbourn and GeoffEley, The Peculiarities of German History. Bourgeois Society and Politics in Nineteenth-Century Germany (New York, 1984). By now the new interest extends to the thesis advisors of some of academic history's next generation of practitioners. A recent graduate student workshop at Harvard (November 1996), for instance, invited apprentice historians from across North America to present their research on the general theme of "Liberalism and Civil Society in Modern Britain and Germany."

${ }^{18}$ Gerald Stourzh, "Zur Institutionengeschichte der Arbeitsbeziehungen und der sozialen Sicherung - eine Einführung," in Stourz and Margarete Grandner, eds., Historische Wurzeln der Sozial Partnerschaft (Munich, 1986), esp. 25-28; Pieter M. Judson, Exclusive Revolutionaries: Liberal Politics, Social Experience, and National Identity in the Austrian Empire, 1848-1914 (Ann Arbor, 1996). Judson's study won the American Historical Association's Herbert Baxter Adams Prize for the best book in European history in 1998. See, as well, Judson's Wien Brennt! Die Revolution von 1848 und ihr liberales Erbe (Vienna, 1998).

${ }^{19}$ Though the emphasis in his work has always been on old-style liberalism's demise due to its loss of "social relevance," John Boyer himself notes that after 1867 in Austria liberals created a hybridized civil society in which extensive protections for individual rights and mechanisms for effective political action coexisted and interlaced with broad bureaucratic imperatives. It was, in his words, a uniquely "complex system of neocorporate and institutional privileges [emphasis added]," a "mixed constitutional-bureaucratic political system in which the German Bürgertum and the Imperial bureaucracy both gained considerable leverage against the ruling sovereign. The Austrian system combined both municipal and regional political autonomy with state centralism to an extent unprecedented in Prussia or the rest of central Europe." John W. Boyer, "Freud, Marriage, and Late Viennese Liberalism: A Commentary from 1905," The Journal of Modern History 50 (March 1978): 73. See also Cohen, "Neither Absolutism nor Anarchy," 44-48. 
${ }^{20}$ Lothar Höbelt, Kornblume und Kaiseradler: Die deutsch-freiheitlichen Parteien Altösterreichs 1882-1918 (Vienna and Munich, 1993).

${ }^{21}$ One of the earliest liberals to learn this was Karl Lueger, who defected to the Christian Social camp and created a powerful political machine in Vienna using the political strategies of what would now be termed "negative integration." On Lueger's early career as a liberal, see Karin Brown, Karl Lueger, the Liberal Years: Democracy, Municipal Reform, and the Struggle for Power in the Vienna City Council, 1875-1882 (New York, 1987).

${ }^{22} \mathrm{Of}$ course, World War I did occur, and so in hindsight we have to take these extremists most seriously - which most of their contemporaries did not. If one insists on reading things against the grain, there were other, "social liberal" fringe groups on the evolving German left who ought to be remembered as well as the Schönerianer, since something like the reformist liberal system they envisioned has, today, been in place in Central Europe for close to half a century. Cf. Eva Holleis, Die Sozialpolitische Partei: Sozialliberale Bestrebungen in Wien um die Jahrhundertwende (Munich, 1978); Ingrid Belke, Die sozialreformischen Ideen von JosefPopper-Lynkeus (1838-1921) in Zusammenhang mit allgemeinen Reformbestrebungen des Wiener Bürgertums um die Jahrhundertwende (Tübingen, 1979); Karl Holl, Günter Trautmann, and Hans Vorländer, Sozialer Liberalismus (Göttingen, 1986); Richard Charmatz, Deutsch-Österreichische Politik: Studien über den Liberalismus und über die auswärtige Politik Österreichs (Leipzig, 1907); Harry Ritter, "Progressive Historians and the Historical Imagination in Austria: Heinrich Friedjung and Richard Charmatz," Austrian History Yearbook 19-20 (1983-1984), Part I, 78-81.

${ }^{23}$ See the concise but subtle exposition in Judson's work of historical popularization, Wien Brennt!, 144-50.

${ }^{24}$ Boyer's former stress on the liberals' "inability to retain local and regional power bases" after initial reverses on the imperial level in 1879 ("Freud, Marriage, and Late Viennese Liberalism," 74) has been proven wrong by subsequent research. It is now widely agreed that our understanding of civic culture and its vitality in late Habsburg Austria has been skewed by focusing so much on Vienna which, except for the fact that it was the imperial seat, was in many ways only one of many diverse regional cases.

${ }^{25}$ Höbelt's Kornblume und Kaiseradler argues that, even on the imperial level, liberals were more politically successful than was previously thought. Thus, in modified form, liberal structures and habits of thought and action remained alive, sustained in part by a corporatism compatible with the enlightened bureaucratism of Josefinian rationalism and the more democratic mechanisms of the constitutional Rechtsstaat. One of his more novel ideas in this regard is that the convoluted system of government by threat of emergency decree employed by Austria's prime ministers after 1900 was rather suited to local circumstances, and actually worked, if not always well. At least there was not paralysis.

${ }^{26}$ WolfgangMantl,"Historischeundaktuelle Aspektederösterreichischen Verfassungsentwicklung seit 1918," Österreich in Geschichte und Literatur 36 (1992) 6: 368.

${ }^{27}$ On this subject see Max Riedelsperger, The Lingering Shadow of Nazism: The Austrian Independent Party Movement Since 1945(New York, 1978); idem., "FPÖ: Liberal or Nazi?" in Conquering the Past: Austrian Nazism Yesterday and Today, ed. Francis Parkinson (Detroit, 1989): 257-78.

${ }^{28}$ Wieser, in his Gesetz der Macht (Vienna, 1926), may be a case in point.

${ }^{29}$ Elisabeth Domansky, "Militarization and Reproduction in World War I Germany," in Geoff Eley, ed., Society, Culture, and the State in Germany, 1870-1930 (Ann Arbor, 1996), 433- 
34. On this point vis-à-vis Germany, see also the concluding chapter of David Blackbourn's The Long Nineteenth Century: A History of Germany, 1780-1918 (New York, 1998). ${ }^{30}$ For a concise discussion, see Binder, "The Second Republic," esp. 19-28 and 36-43.

${ }^{31}$ On West Germany, see Werner Abelshauser, "The First Post-Liberal Nation: Stages in the Development of Modern Corporatism in Germany," European History Quarterly 14 (1984): 285-318. The main pillars of Austria's complicated system, put in place in the late 1950s and early 1960s, were the chambers of labor, agriculture, and commerce (with compulsory membership); a tightlycentralized labor force under the Österreichischer Gewerkschaftsbund; the Joint Commission on Wages and Prices (Paritätatische Kommission - the linchpin of the scheme, bringing together state bureaucrats, party, and union leaders, formed in 1957); and a governing tradition of grand coalitions between the two main parties (although the ÖVP ruled on its own from 1966 to 1970 , and the Socialists governed either alone or with the small third party, the Freiheitliche Partei Österreichs [FPÖ] from 1970 to 1986). For a brief overview see Andrei S. Markovits, "Austrian Corporatism in Comparative Perspective," in Bischof and Pelinka, eds., Austro-Corporatism: Past, Present, Future, 5-20.

${ }^{32}$ The title of Kurt Waldheim's book notwithstanding-The Austrian Example (New York, 1973). The German title is actually Der Österreichische Weg.

${ }^{33}$ Schmitter, "Corporatism," 197.

${ }^{34}$ As Tony Judt has said in a well-informed essay, "It has been a long time since Austria mattered much for anyone who doesn't live there" (which is precisely what Austrian supporters of Anschluss in all ideological camps feared during the 1920s and 1930s). New York Review of Books, Feb. 15, 1996, 22.

${ }^{35}$ Hans-Georg Betz, "The Transformation of the Austrian Party System 1986-1996," unpublished conference paper, German Studies Association, Seattle, October, 13, 1996.

${ }^{36}$ Ibid., 12.

${ }^{37}$ Diethelm Prowe, "“Classic' Fascism and the New Radical Right in Western Europe: Comparisons and Contrasts," Contemporary European History 3 (1994): 289-312.

${ }^{38} J u d s o n$, Wien Brennt!, aptly characterizes this language as "a strange blend of shrill, defensive, nationalist rhetoric and the most radically progressive, optimistic assertions of the effectiveness of education and science for the good of mankind" (150; see also 151-55).

${ }^{39}$ Barbara Haider, Die Protokolle des Verfassungsausschusses des Reichsrates vom Jahre 1867 (Vienna, 1997).

${ }^{40}$ Ibid., 11.

${ }^{41}$ The Times Literary Supplement, Jan. 16, 1998, 6. As this article went to press the following essay by Peter Pulzer, closely related in its concerns and some of its suggestions, came to my attention: "Between Collectivism and Liberalism: The Political Evolution of Austria since 1945" in Kurt Richard Luther and Peter Pulzer, eds., Austria 1945-95: Fifty years of the second republic (Aldershot, 1998), 227-33 